\title{
Marginal Value Estimation for the Attributes of the Tameikes via Choice Experiment
}

\author{
Satoshi Nakano $\cdot$ Kazuhiko Nishimura
}

Received: 28 August 2012 / Accepted: 22 October 2013 /

Published online: 17 November 2013

(C) The Author(s) 2013. This article is published with open access at Springerlink.com

\begin{abstract}
In this study, we conducted a choice experiment for estimating the marginal willingness to pay for the different attributes of the small-scale water reservoirs, known as Tameikes, which are prevalent throughout Japan's inhabitable rural areas. By using Internet surveys, we collected unlabeled five-way choice data from 16,000 respondents residing in the 26 Tameike-abundant prefectures out of the total 47. In this study, we report on the random parameters logit estimates with interacting terms that indicate the differences in the valuation of Tameike attributes with respect to the differences in the respondents' socio-demographic characteristics.
\end{abstract}

Keywords Reservoirs · Valuation · Choice experiment · Random parameters logit · Japan

\section{Introduction}

A Tameike ${ }^{1}$ is a water reservoir that is used for irrigating rice paddies in Japan. Similar facilities can be found across East Asia, and their ancient roots can still be seen in southern India and Sri Lanka. The shapes and appearances of Tameikes are very similar to those of England's small embankment reservoirs. Currently, there are more than 210 thousand

\footnotetext{
${ }^{1}$ Tameike is used hereafter as a countable noun.

S. Nakano

The Japan Institute for Labour Policy and Training, 4-8-23 Kamishakujii, Nerima,

Tokyo 177-8502, Japan

e-mail: nakano@jil.go.jp

K. Nishimura $(\bowtie)$

Faculty of Economics, Nihon Fukushi University, Mihama, Aichi 470-3295, Japan

e-mail: nishimura@n-fukushi.ac.jp

S. Nakano $\cdot$ K. Nishimura

Institute of Chita-hanto Regional Studies, Aichi, Japan
} 
Tameikes, $85 \%$ of which are found in western Japan (MAFF 2013). The top six Tameikeabundant prefectures, ${ }^{2}$ all of which are adjoined to the Seto Inland Sea, contain more than half the country's Tameikes. ${ }^{3}$

The size of a Tameike ranges from several hundred to several hundred-thousand $\mathrm{m}^{3}$ in volume. According to earlier studies, Japan once had about 100 thousand medium- or largesized Tameikes (each irrigating rice paddies with an area measuring a square kilometer or more) that totaled $3.4 \mathrm{~km}^{3}$ in volume (Morita 1982). Although most rice paddies are now connected to aqueducts, the Tameike water-distribution infrastructure is still partly in use. In 1997, Tameike irrigation covered 117 hecto- $\mathrm{km}^{2}$, while the entire area comprised rice paddies in Japan totaled 270 hecto- $\mathrm{km}^{2}$ (MAFF 2013).

Three quarters of the existing Tameikes were developed in the Edo era or earlier, and are well over 150 years old. In the early days, people used Tameikes not only for irrigation but also for culturing carps for edible use. Between irrigation periods, Tameikes were unplugged, drained, and dried for raking sludge to fertilize the paddies. In later years, many Tameikes in the low rainfall areas were connected with larger, more stable water sources (e.g. remote rivers) through a large-scale irrigation system (called Yosui). Generally, this system is connected to larger Tameikes so as to utilize their subordinate irrigation infrastructures. This caused, the smaller and unconnected Tameikes to become inefficient. Additionally, the recent rice paddy reduction program and urbanization promotion policies, along with the aging of the farm population caused the number of Tameikes in use to drastically decrease (MAFF 2013).

Currently, Tameikes are maintained for different purposes besides irrigation; their underlying concept is often referred to as multifunctional. ${ }^{4}$ For example, Tameikes can be naturally used for firefighting, recreational fishing, or ecological cultivation. Matsuno et al. (2006) highlight that irrigation canals and reservoirs perform the function of flood control in both the mountainous and lowland areas. Recently, Tameikes have been gaining interest for their potential of rearing biodiversity as do natural wetlands, preserving the landscape, and also for rejuvenating the rural community.

However, we must say that current management and maintenance of the Tameikes is far from successful. The Tameikes have been experiencing many problems. For example, illegal dumping frequently occurs. Every year we hear of child drowning fatalities in the Tameikes. There are tangled fishing lines all over the place. Some of the Tameikes, especially in the lowland areas, are eutrophied due to living drainage and also cormorant droppings. In urban areas, complaints of odor around the Tameikes are common. And most notably, many Tameikes have been abandoned, along with a large number of arable rice paddies.

Nevertheless, properly managing and maintaining the Tameike could result in considerable social benefits. Instead of railings with barbed-wire fences, urban Tameikes could be furnished with walkways and benches. Instead of having durable, but less amenable concrete embankments, shorelines could be kept natural or be landscaped so as to resemble a natural taste. Whenever a Tameike is unplugged, drained and dredged, foreign game-fishing species could be eliminated. And all such management and maintenance policies ultimately

\footnotetext{
${ }^{2}$ In descending order, these are Hyogo, Hiroshima, Kagawa, Yamaguchi, Osaka, and Okayama.

${ }^{3}$ Note that the formal counter word for Tameikes in Japanese was "Oh" with a character that closely resembles the name of the grand-master Kobo of the Buddhist teaching Shingon, who helped develop one of the oldest Tameikes, the Manno, in Kagawa, around AD 821.

${ }^{4}$ Groenfeldt (2006) advocates that the multifunctionality of agricultural water is appreciated in the old world such as Asia and Europe, rather than in the new world, such as the US, Canada, and Australia.
} 
come down to the measurement of a Tameike's non-market, multi-functional value, which is associated with its considerable social benefit.

There is extensive literature on non-market valuation of various aquatic environments and services, many of which are concerned with the choice experiment method. They include Adamowicz et al. (1994) on water-based recreation in Alberta; Morrison et al. (1999) on the Macquarie Marshes wetland in Australia; Carlsson et al. (2003) on the wetland area in Staffanstorp, Sweden; Othman et al. (2004) on the mangrove wetlands in Malaysia; Hanley et al. (2006) on the improvements to the UK's river ecology; Birol et al. (2006) on the Cheimaditida wetland in Greece; Birol et al. (2009) on flood risks, recreation, and biodiversity conservation of the Bobrek catchment in Poland; Birol and Das (2010) on the wastewater treatment system for the River Ganga in India; and more recently, Martin-Ortega et al. (2011) on the water quality of the Guadalquivir river basin in Spain.

The present study contrasts with the previous ones in that the anthropogenic Tameikes, which comprise this study, exist in large number, and are scattered throughout Japan's rural inhabitable areas. For our study, we used the Internet to conduct a choice experiment survey, visually showing and broadly asking about people's preferences from among the Tameikes' differentiated attributes. By so doing, we estimated the marginal willingness to pay (WTP) for the various differing attributes and characteristics, among the Tameikes, that are useful for assessing their monetary values. In this study we collected unlabeled five-way choice data from 16,000 respondents who resided in the 26 Tameike-abundant prefectures out of the total 47 . We report on the random parameters logit estimates with interacting terms that indicate the differences in Tameike-attribute valuations to the differences in the respondents' socio-demographic characteristics.

In what follows, Section 2 describes the survey design for the Tameikes choice experiment. Section 3 briefly outlines the model structure. Section 4 presents the estimation results, and Section 5 concludes.

\section{Methodology}

\subsection{Random Parameters Logit}

The choice experiment method is based on Lancaster's model of consumer choice (Lancaster 1966). The econometric investigation is based on the random utility theory. We briefly introduce the main idea of the methodology used in our analysis as follows. The decision maker faces a choice among $J$ alternatives. The utility $U$ of a decision maker (person) $n$ from alternative $j$ is assumed to be additively decomposed into the systematic component $V$ and a stochastic component specified as

$$
U_{n j}=V_{n j}+\varepsilon_{n j}=\beta_{n}^{\prime} x_{n j}+\varepsilon_{n j}
$$

where, $x_{n j}$ are the observed variables that relate to the alternative and the decision maker (i.e., quantified attributes and characteristics), $\beta_{n}$ is a vector of coefficients representing $n$ 's tastes, and $\varepsilon_{n j}$ is a random term that is assumed to be the IID type I extreme value. Standard conditional logit is the case where $\beta_{n}=\beta$ such that the probability $P$ of $n$ choosing $i$ can be expressed in a simple logit formula $P_{n i}=e^{\beta^{\prime} x_{n i}} / \sum_{j} e^{\beta^{\prime} x_{n j}}$. However, such models entail restrictive substitution patterns (i.e., independence from irrelevant alternatives (IIA)).

In the case of a random parameters logit, which avoids IIA, specification (1) is generalized by allowing $\beta_{n}$ to vary over decision makers in the population with some density $f(\beta \mid \theta)$ with parameter $\theta$ such as mean and covariance of $\beta$. The decision maker $n$ knows 
the value of $\beta_{n}$ and $\varepsilon_{n j}$ for all $j$ and chooses alternative $i$ if and only if $U_{n i}>U_{n j}, \forall j \neq i$. The researcher observed the $x_{n j}$ but not $\beta_{n}$. Thus, conditional on $\beta_{n}$, the probability that the decision maker $n$ chooses the alternative $i$ is the standard logit formula given below:

$$
L_{n i}\left(\beta_{n}\right)=\frac{e^{\beta_{n}^{\prime} x_{n i}}}{\sum_{j} e^{\beta_{n}^{\prime} x_{n j}}}
$$

However, since $\beta_{n}$ is random and unknown, the (unconditional) choice probability is the integral of this logit formula over the density of $\beta_{n}$.

$$
P_{n i}=\int L_{n i}(\beta) f(\beta \mid \theta) d \beta=\int \frac{e^{\beta^{\prime} x_{n i}}}{\sum_{j} e^{\beta^{\prime} x_{n j}}} f(\beta \mid \theta) d \beta
$$

The probabilities are approximated through simulation for any given value of $\theta$. Let $\beta^{r}$ be the $r=1, \cdots, R$ th draw from $f(\beta \mid \theta)$, and we have the simulated probability:

$$
\check{P}_{n i}=\frac{1}{R} \sum_{r=1}^{R} L_{n i}\left(\beta^{r}\right)
$$

The simulated probabilities are inserted into the log-likelihood function to give the following simulated log likelihood:

$$
\mathrm{SLL}=\sum_{n=1}^{N} \sum_{j=1}^{J} d_{n j} \ln \check{P}_{n i}
$$

where, $d_{n j}=1$ if $n$ chose $j$, and 0 otherwise. The maximum simulated likelihood estimator (MSLE) is the value of $\theta$ that maximizes the above SLL. On the other hand, coefficients are treated as fixed in the case of the standard conditional logit (CL) estimation.

\subsection{Socio-demographic Variables}

By definition, the decision maker's characteristics (socio-demographic variables) do not vary across the alternatives. As a result, they can only enter the model in ways that create differences in utility over the alternatives (Train 2009). Although we may expect that the effect of the socio-demographic variables differ across alternatives, since only the differences in the utility matter, the absolute parameter levels cannot be estimated. For a labeled analysis, this problem is dealt by normalizing one parameter and measuring the differential impact of the socio-demographic variable on the utility of an alternative, relative to the normalized alternative. For an unlabeled analysis, such as the current case, interaction terms are used. As the socio-demographic variables affect the differences in the utility through their interaction with the attributes of the alternatives, the parameters for the interaction terms are estimated instead of those for the socio-demographic variables.

The interaction terms appear when we consider that the parameters specific to individual $n$ are assumed to vary across individuals. Suppose the value of $x_{j}$ for each individual depends on some observed characteristic $z_{n}$ and some random component $\mu_{n}$, then

$$
\beta_{n}=\gamma z_{n}+\mu_{n}
$$

In this case, the random utility specification is as follows:

$$
\beta_{n}^{\prime} x_{j}+\varepsilon_{n j}=\gamma^{\prime} z_{n} x_{j}+\mu_{n}^{\prime} x_{j}+\varepsilon_{n j}
$$




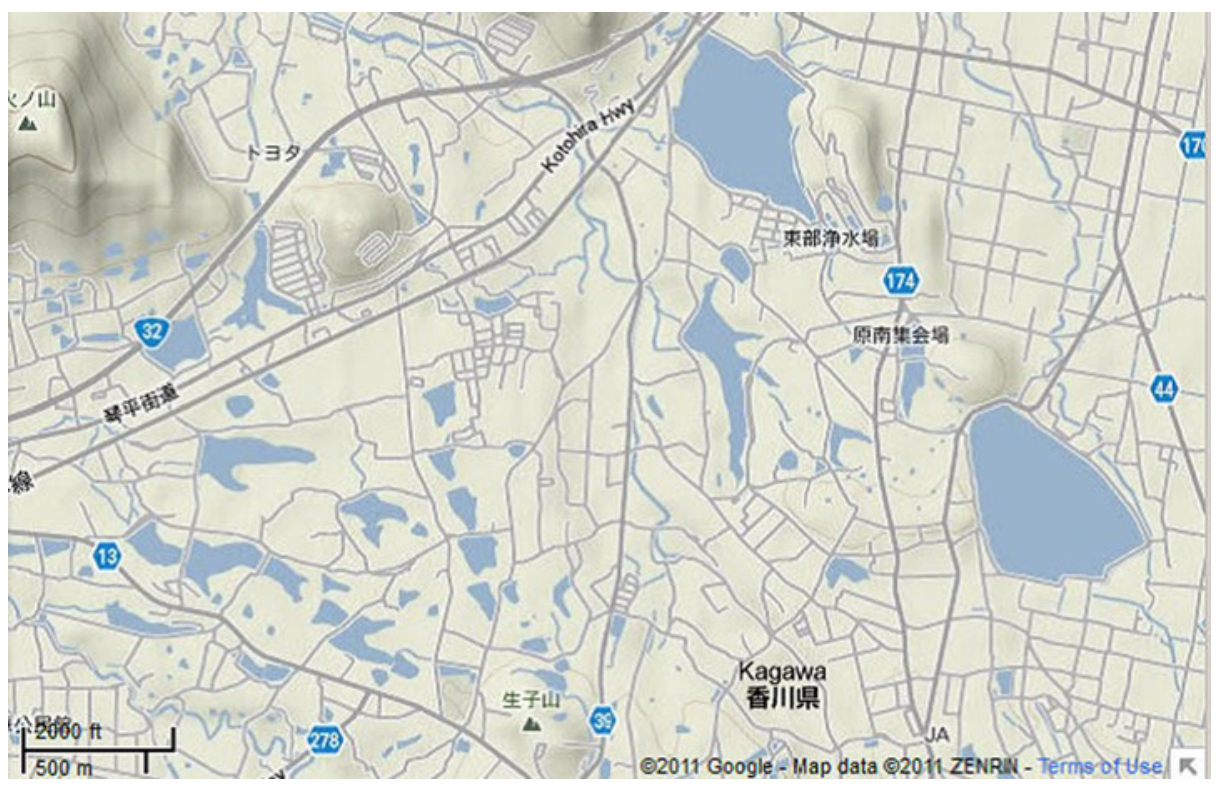

Fig. 1 Google Map screenshot of the Sanuki Plain, Kagawa. Observe the wedge-shaped Yama-type and the round dish-like Sara-type Tameikes

As for the logit models estimating $\gamma$, the error term $\mu_{n}^{\prime} x_{j}+\varepsilon_{n j}$ has to be IID, while this condition can be met only if $\mu_{n}$ is not random. In other words, we will be assuming that tastes (i.e., $\beta_{n}$ ) are expected to systematically vary in relation to the observed variables $z_{n}$.

\section{Tameike Choice Experiment}

\subsection{Choice Experiment Design}

Our choice experiment concerns the Tameikes, which are prevalent throughout (mainly western) Japan. Essentially, there are two types of Tameikes. First is a wedge-shaped "Yamaike", which exists in a valley and has an embankment on one side. These Yama-type Tameikes are seen in places that are relatively remote from settlements. The other type is the round dish-like "Saraike". Sara-type Tameikes are mostly seen near or within settlements, on more or less flat land. Figure 1 is a screen shot of the Sanuki Plain, in Kagawa, in which both types of Tameikes can be seen.

We used the Internet for this choice experiment. While certain attributes of the Tameikes, such as water quality and the surrounding environment, can be presented through visual images, the Internet is also very useful for data collection. Rakuten Research Inc., a Japanese market research company, conducted our survey. This company has over two million registrants who could potentially answer the questionnaires online. ${ }^{5}$ And since the Tameikes

\footnotetext{
${ }^{5}$ Rakuten registrants gain Rakuten points for participating in an online survey, which can be used for such purposes as on-line shipping from Rakuten.
} 
are prevalent across the country, it was preferable that the survey cover respondents evenly across the country, while controlling for age, income group, and other variables. Rakuten Rsearch Inc.'s Internet survey met these criteria.

To determine which Tameike attributes were important and effective, we performed a preliminary survey prior to the main choice experiment. To accomplish this, we asked the participants of the Tameike Symposium 2007, held in Aichi, about the attributes people would value and the possible range of payments they would be willing to make for maintaining an environmentally sound Tameike. Subsequently, we designated the attributes noted in the Tameike Symposium survey for the Rakuten Research Inc. survey, the results of which are summarized in Table 1. Both Yama- and Sara-type Tameikes were assessed according to the five attributes of the surroundings arrangement, shoreline revetment, water quality, fish, and total cost; Distance (from the respondent's residence to the Tameike); and Size (of the relevant Tameike) were differentiated between the Yama- and Sara-types, reflecting typical locations and figures for both types of Tameikes.

In the introduction of the choice experiment, the purpose of conserving the Tameikes and their two types (Yama- and Sara-types) was explained. With the aid of images (photographs), the respondents were informed about the Tameikes' current situation, both the abandoned and the managed ones. The attributes used in the choice experiment were also explained with the aid of images. For each respondent, we outlined the Distance and the Size for the two types of Tameikes, and their basic respective characteristics i.e., with a

Table 1 Atrributes and attribute levels used in the choice experiment

\begin{tabular}{|c|c|c|}
\hline Attributes & Description & Levels \\
\hline Distance & $\begin{array}{l}\text { Distance from residence to the Tameike, where Yama-types are } \\
\text { always farther than the Sara-types. }\end{array}$ & $0.2,0.9 ; 1,5(\mathrm{~km})$ \\
\hline Size & Size of the Tameike measured by the periphery. & $0.3,1(\mathrm{~km})$ \\
\hline $\begin{array}{l}\text { Surroundings } \\
\text { arrangement }\end{array}$ & $\begin{array}{l}\text { The surroundings of a Tameike could be either enclosed by wire } \\
\text { meshed fences, or by walkways and benches. Samples were shown } \\
\text { to the respondents through images. }\end{array}$ & fences $^{\mathrm{a}}$, walkways \\
\hline $\begin{array}{l}\text { Shoreline } \\
\text { revetment }\end{array}$ & $\begin{array}{l}\text { The shoreline of a Tameike could be either kept natural, embanked } \\
\text { with concrete, or furnished with boardwalks.Samples were shown } \\
\text { to the respondents through images. }\end{array}$ & $\begin{array}{l}\text { natural }^{\mathrm{a}}, \text { concrete } \\
\text { boardwalks }^{2}\end{array}$ \\
\hline Water quality & $\begin{array}{l}\text { Quality of Tameike water in four levels. With quality high, the } \\
\text { water is very clear; with quality low, the water is very cloudy with } \\
\text { odor; mid-high and mid-low lies in between. Samples were shown } \\
\text { to respondents through images. }\end{array}$ & $\begin{array}{l}\text { high, mid-high, } \\
\text { mid-low, low }\end{array}$ \\
\hline Fish & $\begin{array}{l}\text { There are fish of Asian native species such as carps and gibel } \\
\text { carps in the Tameikes. However, non-native (alien) species such as } \\
\text { black bass and blue gill may be introduced for luring game fishing, } \\
\text { and some will have a mixture of both species. }\end{array}$ & native, alien, mix ${ }^{\mathrm{a}}$ \\
\hline Total cost & $\begin{array}{l}\text { The total monthly payment for the individual if the alternative } \\
\text { was chosen. }\end{array}$ & $\begin{array}{l}0^{\mathrm{a}}, 0.3,0.7,1.1 \\
1.5(\mathrm{kJPY} / \mathrm{month})\end{array}$ \\
\hline
\end{tabular}

${ }^{\mathrm{a}}$ Levels indicate the base (uncontrolled) alternative 
Yama-type being smaller and more distant from the respondent, and the Sara-type Tameikes being larger and nearer the respondent. In the choice experiment, each respondent answered two choice sets: first for the Yama-, and then for the Sara-type. In each choice set, they were asked to choose from among five possible alternatives. The first alternative was always the base alternative, in which there were to be no improvements to the Tameike at no cost.

The choice sets for the main experiment were created by using SPSS-Orthoplan, which generates main-effects orthogonal fractional factorial plans. From the collective factorial that amounts to $2^{3} \times 3^{4}$ for either type of Tameike, 64 treatment combinations (profiles) were generated. We then grouped them into four blocks with 16 treatment combinations, each with the same first and second attribute levels because these attributes (Distance and Size) were regarded as inflexible, as they were essential in distinguishing between the images of the two types of Tameikes in our choice experiment. That is, all 16 treatment combinations in one block have the same first and second attribute levels, whereas they differ over all four blocks.

Since our choice experiment was unlabeled, we randomized the 16 treatment combinations thrice to obtain 16 choice sets, with four alternatives, that retain the within-alternative orthogonality. ${ }^{6}$ In each choice set, the base (uncontrolled) alternative with the lowest levels of water quality and total cost (no cost) was included as the fifth alternative. All four blocks were treated in the same manner. This five-way choice experiment was performed sequentially for Yama- and Sara-types. An example of a choice situation is presented in Appendix A.

\subsection{Survey and Coding}

The online Tameike choice experiment survey was performed in October 2011. We assigned all 16 five-way choice sets to each segment of respondents, while assigning a single five-way choice set to each respondent. The segmentation of respondents is based on the cross section of age ( 6 categories), sex ( 2 categories), and prefecture (26 categories). We distributed a total of 1,000 units to all segments at a minimum of one unit, according to the proportion of the population for each segment, and assigned 16 choice sets to each unit, thereby obtaining data from 16,000 respondents. The 26 prefectures western Japanese prefectures selected (out of the total 47) indlude Shizuoka, Aichi, Gifu, Shiga, and Kyoto along the border.

Table 2 presents the descriptive statistics of the sample used in the estimations. The attributes of the alternatives for the choice sets are different between the Yama- and Saratype surveys because of the difference in randomizing the treatment combinations. The choice experiment data were coded according to the level of attributes: Two possible options for surroundings arrangement were coded using one binary variable, while three possible options for shoreline revetment were coded using two binary variables. Attributes for fish were also coded using two binary variables. Four levels of water quality were coded using integers that range from 0 to 3 .

Binary variables were used to capture the socio-demographic characteristics such as the respondent's sex, employment status (employed or not), marital status (married or not), and the presence of a household member under 18 or over 65 years of age. The distance and size

\footnotetext{
${ }^{6}$ For details in unlabeled experiment design, see e.g., Hensher et al. (2005).
} 
Table 2 Attributes of Tameikes and socio-demographic characteristics of the respondents

\begin{tabular}{|c|c|c|c|}
\hline \multirow[t]{2}{*}{ Attribute/Characteristic } & \multicolumn{2}{|c|}{ Sample mean (s.d.) } & \multirow[b]{2}{*}{ Sara-type } \\
\hline & Yama-type & & \\
\hline surroundings arrangement: fences $=1,0$ otherwise & $0.45(0.50)$ & & $0.55(0.50)$ \\
\hline shoreline revetment: boardwalks $=1,0$ otherwise & $0.18(0.38)$ & & $0.24(0.43)$ \\
\hline shoreline revetment: concrete $=1,0$ otherwise & $0.24(0.43)$ & & $0.17(0.37)$ \\
\hline water quality (4 levels) & $2.03(1.06)$ & & $2.20(1.03)$ \\
\hline fish: native $=1,0$ otherwise & $0.47(0.50)$ & & $0.63(0.48)$ \\
\hline fish: alien $=1,0$ otherwise & $0.21(0.41)$ & & $0.11(0.31)$ \\
\hline total cost (5 levels in JPY/month) & $722.88(473.30)$ & & $642.93(468.92)$ \\
\hline distance $^{\mathrm{a}}$ (2 levels in $\left.\mathrm{km}\right)$ & $3.00(2.83)$ & & $0.55(0.49)$ \\
\hline$s_{i z e}$ a (2 levels in km periphery) & & $0.65(0.49)$ & \\
\hline sex: female $=1,0$ otherwise & & $0.52(0.50)$ & \\
\hline age & & $41.03(13.51)$ & \\
\hline employed $=1,0$ otherwise & & $0.68(0.47)$ & \\
\hline married $=1,0$ otherwise & & $0.72(0.45)$ & \\
\hline household income (in million JPY) & & $6.20(0.57)$ & \\
\hline household savings (in million JPY) & & $4.89(2.43)$ & \\
\hline household has member of age under $18=1,0$ otherwise & & $0.35(0.48)$ & \\
\hline household has member of age over $65=1,0$ otherwise & & $0.26(0.44)$ & \\
\hline
\end{tabular}

a distance and size were differentiated respondent-wise

of the Tameikes were included in the respondent's characteristics, since these attributes were differentiated respondent-wise. Each respondent was given a five-way choice set where alternatives were indifferent in terms of the levels of Distance and Size. The respondents were asked to choose from among the ranged segments that they belonged to for the levels of household income and savings. For these variables, we used the log of the central value for each segment.

\section{Results}

\subsection{Parameters Estimation}

We used Limdep/Nlogit to estimate the random parameter logit (RPL) models via the MSLE discussed earlier. The Lagrange Multiplier test (McFadden and Train 2000) was used for selecting effective variables for random parameters. As a result, quality and native were selected for Yama-types, while boardwalks, native, and alien were selected for Sara-type Tameikes. For the likelihood simulation, the samples were drawn from a standard normal density using Halton draws with 1,000 replications. The estimated parameters are presented in Table 3 for Yama-type and Table 4 for Sara-type Tameikes. Models 1 and 4 show the RPL estimates for the Tameiks' attributes, while Models 2 and 5 show those with 
interaction terms between the random parameter attributes and the socio-demographic variables. Models 3 and 6 show the significance of the estimates of the selected variables. The RPL is employed in this study to circumvent the IIA restriction on the substitution patterns that CL models naturally impose. Estimates of CL models are reported in the Appendix B, for reference. For both Yama- and Sara- types, the acceptance of IIA was rejected with the Hausman-McFadden (HM) test statistic being very large and statistically significant well below the $1 \%$ level (Tables 6 and 7). This suggests that estimating both models as CL could generate misleading results.

As the models are nested in nature, we may use the log likelihood-ratio test for binary model comparisons. For $\mathrm{H}_{0}$ : Model $1=$ Model 3 vs. $\mathrm{H}_{1}$ : Model $1 \neq$ Model 3 , the test statistic $-2 \mathrm{LLR}=166$ under $\chi^{2}(7)$ indicates a rejection of $\mathrm{H}_{0}$ at a $1 \%$ significance level. For $\mathrm{H}_{0}$ : Model $2=$ Model 3 vs. $\mathrm{H}_{1}$ : Model $2 \neq$ Model 3, $-2 \mathrm{LLR}=18$ under $\chi^{2}(13)$ indicates that we may not reject $\mathrm{H}_{0}$ even at a $10 \%$ significance level. For $\mathrm{H}_{0}$ : Model 4 $=$ Model 6 vs. $\mathrm{H}_{1}$ : Model $4 \neq$ Model $6,-2 \mathrm{LLR}=1378$ under $\chi^{2}(14)$ indicates a rejection of $\mathrm{H}_{0}$ at a $1 \%$ significance level. For $\mathrm{H}_{0}$ : Model $5=$ Model 6 vs. $\mathrm{H}_{1}$ : Model $5 \neq$ Model 6, -2LLR $=14$ under $\chi^{2}(16)$ indicates that we may not reject $\mathrm{H}_{0}$ even at a $10 \%$ significance level. Hence, Model 3 and 6 are the best-fit models among the alternatives, for Yama- and Sara-type Tameikes, respectively. The following analysis is based on these models.

For Yama-type Tameikes, the estimates (Model 3) show that the building of walkways and benches is preferred over having just wire-meshed fences for the surroundings arrangement. As for the shoreline revetment, furnishing with boardwalks is preferred over keeping it natural; however, a concrete embankment is not favored. Tameikes inclusive of Asian native carps and gibel carps but exclusive of alien species, such as black bass and blue gill, are preferred over those with a mixture of both. Furthermore, those inclusive of alien species but exclusive of the native ones are undesirable. The results show (with the expected signs) that better water quality and lower administration costs are both strictly preferred.

On the other hand, for Sara-types, the estimates (Model 6) show that wire-meshed fences are preferred to building walkways and benches, with respect to the surroundings arrangement. As for the shoreline revetment, untouched natural features are favored over those with boardwalks or concrete embankments. As for the fish species, Tameikes with a mixture of both native and alien species were favored over those with either one type of species or another (native or non-native). Whereas lower administration costs were favored, as expected, lower water quality was also favored in the case of the Sara-type Tameikes.

Yama-type Tameikes, or the wedge-shaped ones that are typically seen in remote places, are expected in general, to be maintained for decent recreation purposes. Avoidance of concrete embankments, preference for good water quality, and a preference for native fish species perhaps all fall into the class of concepts that are conscious of the environment. However, the Sara-type Tameike, which are mainly located near or within the settlements, are merely expected to subsist, and only to be surrounded by meshed-iron fences. Good water quality and a specific preference for either of the fish species are of less concern. Aside from the following discussion on interacting terms, the Sara-type Tameikes appear to be of less interest in general.

Models 3 and 6 show the estimated parameters for the interaction terms so that we can verify the influences of the sociodemographic variables against the attributes with random parameters. Note that the standard deviations of the random parameter distributions 
Table 3 RPL estimates with interactions for Yama-type Tameikes

\begin{tabular}{|c|c|c|c|}
\hline Variables & $\begin{array}{l}\text { Model } 1 \\
\text { Coefficient (s.e.) }\end{array}$ & $\begin{array}{l}\text { Model } 2 \\
\text { Coefficient (s.e.) }\end{array}$ & $\begin{array}{l}\text { Model } 3 \\
\text { Coefficient (s.e.) }\end{array}$ \\
\hline quality (random) & $0.609(0.020)^{* * *}$ & $0.343(0.133)^{* * *}$ & $0.387(0.037)^{* * *}$ \\
\hline native (random) & $0.934(0.043)^{* * *}$ & $0.922(0.244)^{* * *}$ & $0.477(0.085)^{* * * *}$ \\
\hline walkways & $0.860(0.026)^{* * *}$ & $0.860(0.026)^{* * *}$ & $0.860(0.026)^{* * *}$ \\
\hline boardwalks & $0.334(0.028)^{* * *}$ & $0.348(0.029)^{* * *}$ & $0.346(0.028)^{* * *}$ \\
\hline concrete & $-0.430(0.035) * * *$ & $-0.425(0.035)^{* * *}$ & $-0.428(0.035)^{* * *}$ \\
\hline alien & $-0.383(0.040)^{* * *}$ & $-0.385(0.040)^{* * *}$ & $-0.384(0.040)^{* * *}$ \\
\hline $\cos t$ & $-0.001(0.000)^{* * *}$ & $-0.001(0.000)^{* * *}$ & $-0.001(0.000)^{* * * *}$ \\
\hline age $\times$ quality & & $-0.000(0.001)$ & \\
\hline age $\times$ native & & $0.010(0.002)^{* * *}$ & $0.011(0.002)^{* * *}$ \\
\hline sex $\times$ quality & & $0.149(0.023)^{* * *}$ & $0.150(0.021)^{* * * *}$ \\
\hline se $x \times$ native & & $0.008(0.041)$ & \\
\hline employed $\times$ quality & & $0.016(0.025)$ & \\
\hline employed $\times$ native & & $-0.019(0.045)$ & \\
\hline married $\times$ quality & & $0.046(0.028)$ & \\
\hline married $\times$ native & & $0.076(0.051)$ & \\
\hline income $\times$ quality & & $0.002(0.022)$ & \\
\hline income $\times$ native & & $-0.064(0.040)$ & \\
\hline savings $\times$ quality & & $0.013(0.005)^{* *}$ & $0.013(0.004)^{* * *}$ \\
\hline savings $\times$ native & & $0.018(0.009)^{* *}$ & $0.014(0.008)^{*}$ \\
\hline under $18 \times$ quality & & $0.021(0.025)$ & \\
\hline under $18 \times$ native & & $-0.084(0.045)^{*}$ & \\
\hline over $65 \times$ quality & & $-0.020(0.026)$ & \\
\hline over $65 \times$ native & & $0.094(0.047)^{* *}$ & $0.084(0.045)^{*}$ \\
\hline distance $\times$ quality & & $0.000(0.006)$ & \\
\hline distance $\times$ native & & $-0.016(0.011)$ & \\
\hline size $\times$ quality & & $0.124(0.032)^{* * *}$ & $0.126(0.032)^{* * *}$ \\
\hline size $\times$ native & & $-0.113(0.061)^{*}$ & $-0.111(0.060)^{*}$ \\
\hline Sample size & 16,000 & 16,000 & 16,000 \\
\hline Log likelihood & $-20,792$ & $-20,700$ & $-20,709$ \\
\hline McFadden Pseudo $\mathrm{R}^{2}$ & 0.193 & 0.196 & 0.196 \\
\hline \multicolumn{4}{|c|}{ Standard deviations of random parameter distributions: } \\
\hline quality & $0.553(0.038)^{* * *}$ & $0.551(0.038)^{* * *}$ & $0.555(0.038)^{* * *}$ \\
\hline native & $0.425(0.251)^{*}$ & $0.448(0.245)^{*}$ & $0.384(0.272)$ \\
\hline
\end{tabular}

$* * *$ indicates significance at $1 \%$ level, ** at $5 \%$, and $*$ at $10 \%$

for quality (Yama-type) and for alien (Sara-type) reveal significant choice-specific unobserved heterogeneity. According to the estimates, for Yama-types, higher water quality is 
Table 4 RPL estimates with interactions for Sara-type Tameikes

\begin{tabular}{|c|c|c|c|}
\hline Variables & $\begin{array}{l}\text { Model } 4 \\
\text { Coefficient (s.e.) }\end{array}$ & $\begin{array}{l}\text { Model } 5 \\
\text { Coefficient (s.e.) }\end{array}$ & $\begin{array}{l}\text { Model } 6 \\
\text { Coefficient (s.e.) }\end{array}$ \\
\hline walkways (random) & $-0.091(0.021)^{* * *}$ & $-1.700(0.228)^{* * *}$ & $-1.413(0.062)^{* * *}$ \\
\hline native (random) & $-0.476(0.026)^{* * *}$ & $-0.198(0.242)$ & $-0.453(0.092)^{* * *}$ \\
\hline alien (random) & $-1.460(0.156)^{* * *}$ & $-7.333(1.458)^{* * *}$ & $-8.063(1.041)^{* * * *}$ \\
\hline boardwalks & $-0.389(0.028)^{* * *}$ & $-0.297(0.029)^{* * *}$ & $-0.297(0.029)^{* * *}$ \\
\hline concrete & $-0.474(0.030)^{* * *}$ & $-0.527(0.029)^{* * *}$ & $-0.526(0.029)^{* * *}$ \\
\hline quality & $-0.185(0.018)^{* * *}$ & $-0.303(0.017)^{* * *}$ & $-0.303(0.017)^{* * *}$ \\
\hline cost & $-0.001(0.000)^{* * *}$ & $-0.001(0.000)^{* * *}$ & $-0.001(0.000)^{* * *}$ \\
\hline age $\times$ walkways & & $0.001(0.002)$ & \\
\hline age $\times$ native & & $0.006(0.002)^{* * *}$ & $0.006(0.002)^{* * *}$ \\
\hline age $\times$ alien & & $0.014(0.008)^{*}$ & $0.018(0.007)^{* *}$ \\
\hline sex $\times$ walkways & & $0.098(0.039)^{* *}$ & $0.104(0.038) * * *$ \\
\hline sex $\times$ native & & $0.112(0.042)^{* * *}$ & $0.121(0.040)^{* * *}$ \\
\hline sex $\times$ alien & & $0.401(0.201)^{* *}$ & $0.358(0.192)^{*}$ \\
\hline employed $\times$ walkways & & $-0.032(0.042)$ & \\
\hline employed $\times$ native & & $-0.032(0.045)$ & \\
\hline employed $\times$ alien & & $0.229(0.217)$ & \\
\hline married $\times$ walkways & & $0.039(0.048)$ & \\
\hline married $\times$ native & & $0.088(0.051)^{*}$ & $0.087(0.045)^{*}$ \\
\hline married $\times$ alien & & $0.231(0.245)$ & \\
\hline income $\times$ walkways & & $0.033(0.038)$ & \\
\hline income $\times$ native & & $-0.039(0.041)$ & \\
\hline income $\times$ alien & & $-0.210(0.194)$ & \\
\hline savings $\times$ walkways & & $0.009(0.008)$ & \\
\hline savings $\times$ native & & $0.024(0.009)^{* * *}$ & $0.021(0.008)^{* *}$ \\
\hline savings $\times$ alien & & $0.073(0.043)^{*}$ & \\
\hline under $18 \times$ walkways & & $0.020(0.043)$ & \\
\hline under $18 \times$ native & & $0.009(0.046)$ & \\
\hline under $18 \times$ alien & & $0.384(0.219)^{*}$ & $0.408(0.204)^{* *}$ \\
\hline over $65 \times$ walkways & & $0.016(0.044)$ & \\
\hline over $65 \times$ native & & $-0.011(0.047)$ & \\
\hline over $65 \times$ alien & & $0.067(0.225)$ & \\
\hline distance $\times$ walkways & & $1.404(0.064)^{* * *}$ & $1.403(0.064)^{* * * *}$ \\
\hline distance $\times$ native & & $0.183(0.059) * * *$ & $0.184(0.059)^{* * *}$ \\
\hline distance $\times$ alien & & $-0.750(0.277)^{* * *}$ & $-0.757(0.276)^{* * *}$ \\
\hline size $\times$ walkways & & $0.527(0.058)^{* * *}$ & $0.527(0.058)^{* * *}$ \\
\hline size $\times$ native & & $-1.021(0.062)^{* * *}$ & $-1.021(0.062)^{* * *}$ \\
\hline size $\times$ alien & & $5.627(0.723)^{* * *}$ & $5.605(0.720)^{* * *}$ \\
\hline Sample size & 16,000 & 16,000 & 16,000 \\
\hline Log likelihood & $-23,900$ & $-23,204$ & $-23,211$ \\
\hline McFadden Pseudo $\mathrm{R}^{2}$ & 0.072 & 0.099 & 0.099 \\
\hline \multicolumn{4}{|c|}{ Standard deviations of random parameter distributions: } \\
\hline walkways & $0.003(0.289)$ & $0.000(0.072)$ & $0.000(0.072)$ \\
\hline native & $0.002(0.081)$ & $0.006(0.105)$ & $0.007(0.105)$ \\
\hline alien & $3.407(0.321)^{* * *}$ & $7.110(0.759)^{* * *}$ & $7.100(0.757)^{* * *}$ \\
\hline
\end{tabular}

*** indicates significance at $1 \%$ level, $* *$ at $5 \%$, and $*$ at $10 \%$ 
preferred by females and by those with large savings. ${ }^{7}$ Native fish species are favored more the aged and those that have greater personal savings, and by those with aged family members. Higher water quality is favored for larger Yama-type Tameikes. In the case of the Sara-type, we observe that surroundings maintained with walkways are favored more by females. Walkways are favored for distant and larger Sara-type Tameikes, while non-native fish species are acceptable for those that live nearby and for large Tameikes. As for fish species for both types of Tameikes, native species are favored more over a mix of different species by those who are older and have larger savings, and by those who are female and married. Aged, female, and high-savings respondents tended to prefer either native or non-native fish species but not a mixture of both. This may imply that respondents tend to prefer that native species not be overtaken by the non-native species.

\subsection{Marginal WTP Estimation}

For linear utility models, the marginal monetary value of change in a single Tameike attribute can be represented as a ratio of coefficients if we use the monetary attribute for the denominator. This part-worth figure represents the marginal rate of substitution between income and the attribute in question (i.e., the marginal willingness to pay for a change in the attribute). In Table 5 we summarize the estimated marginal WTP as a monthly payment in Japanese Yen.

According to the results, for Yama-types, respondents are willing to pay an extra 720 JPY every month for a walkway-maintained Tameike rather than for one with (uncontrolled) wire-meshed fences. They are also willing to pay an extra 280 JPY every month for a boardwalk-furnished Tameike, but are willing to be compensated by having 360 JPY every month if the shoreline of the Tameike is embanked in concrete. For water quality, respondents are willing to pay an extra $510 \mathrm{JPY}$ for a single level improvement. As for fish species, respondents are willing to pay $780 \mathrm{JPY}$ every month to keep a Tameike free of non-native species, while they would be willing to be compensated 320 JPY per month if a Tameike is inhabited by non-native species; however, the numbers here should be carefully assessed, as the estimated standard errors are relatively large. As for the Sara-types, we observe no willingness to pay for improvements to Tameike's environmet. Indeed, the WTP estimates for any attribute that show a negative sign means that respondents feel that any improvement from the uncontrolled condition is not worth paying for.

The WTP estimates we obtained in this study can be compared to previous related studies. On their choice experiment for a wetland in Sweden, Carlsson et al. (2003) report that the marginal WTP for similar attributes matches our findings. They observed positive values for Fish (292 SEK per annum) and Walking Facilities (601) that correspond to our native and walkways (or boardwalks) findings, respectively. And where, in our case, we also observed negative values for Yama-types, they observed negative values for Crayfish $(-184)$ and Fenced Waterline (-56) that correspond to alien and concrete. Notice also that their marginal WTP estimates for these attributes are astonishingly close to ours for the corresponding similar attributes for Yama-type Tameikes.

\footnotetext{
${ }^{7}$ Birol and Das (2010) report similar findings in their CL model with interaction terms. They note that people with higher income levels and education are more likely to pay more for a wastewater treatment program.
} 
Table 5 Marginal willingness to pay for Tameike attributes in JPY/month

\begin{tabular}{|c|c|c|c|c|c|c|}
\hline \multirow[b]{2}{*}{ Variables } & \multicolumn{3}{|c|}{ Yama-types } & \multicolumn{3}{|c|}{ Sara-types } \\
\hline & Model 1 & Model 2 & Model 3 & Model 4 & Model 5 & Model 6 \\
\hline \multirow[t]{2}{*}{ walkways } & 718 & 717 & 715 & -164 & $-2,424$ & $-2,017$ \\
\hline & & & & (6) & (0) & (0) \\
\hline boardwalks & 279 & 290 & 287 & -704 & -424 & -424 \\
\hline concrete & -359 & -354 & -355 & -858 & -751 & -750 \\
\hline \multirow[t]{2}{*}{ quality } & 508 & 286 & 322 & -335 & -433 & -433 \\
\hline & (462) & (459) & (461) & & & \\
\hline \multirow[t]{2}{*}{ native } & 780 & 768 & 397 & -860 & -282 & -646 \\
\hline & (355) & (373) & (319) & (4) & (9) & (9) \\
\hline \multirow[t]{2}{*}{ alien } & -319 & -321 & -319 & $-2,641$ & $-10,454$ & $-11,505$ \\
\hline & & & & $(6,160)$ & $(10,137)$ & $(10,131)$ \\
\hline
\end{tabular}

Standard deviations in parentheses

As for water quality improvements, Bateman et al. (2006), with their contingent ranking study, estimate WTP for the River Tame as 8.64 (GBP per annum) for small, and 21.34 for medium-level improvements of water quality. Hanley et al. (2006) have an RPL estimate for the WTP for two rivers in the UK, obtaining 12.19 (GBP per annum for the River Wear, river ecology) to 42.99 (GBP per annum for the River Clyde, banksides), for river water quality improvements from fair to good. These numbers are fairly comparable to our Yama-type estimate (322 JPY per month) for a marginal improvement in a four-level quality profile.

\section{Conclusion}

This study presents a choice experiment and the discrete choice framework for the case of Japan's Tameikes. As the Tameikes are present all over the country, we evaluated different Tameikes by decomposing valuations into attributes. We used the Internet to obtain a large survey sample. From the partial valuation of attributes, we were able to estimate the marginal willingness to pay monetarily for each of the important Tameike attributes. The use of Internet for the survey ensured spatial and demographic coverage and also facilitated choice among alternatives for the respondents.

The results indicate that respondents typically expect the remote and more natural Yama-type Tameikes to be maintained for decent recreation purposes: good water quality with native Asian fish species are the preferred characteristics, while concrete embankments and non-native species were met with distaste. Such a tendency was greater for those who had more savings, were female, or were living with aged family members. The Sara-type Tameikes, in contrast, were not of much interest, with the willingness to pay estimates for any attribute showing a negative sign. However, female respondents, who perhaps tend to consider these nearby Tameikes as part of their living environment, were 
willing to maintain the surroundings with walkways, which is conceivably a park-type attribute.

Acknowledgments The authors are grateful to the two anonymous reviewers for their valuable comments and advice. The authors are also thankful to Hirokazu Magarida, Hiroyuki Takeya, Akira Akahane, Yuya Kato, Masako Tokunaga and the Rakuten Research Inc. for their valuable comments, assistance, and support, during the course of the study. This research was supported by JSPS grant No. 00351081.

Open Access This article is distributed under the terms of the Creative Commons Attribution License which permits any use, distribution, and reproduction in any medium, provided the original author(s) and the source are credited.

\section{Appendix A: Choice situations}

\section{Sample choice sets}

Consider one Yama-type Tameike of the size about $300 \mathrm{~m}$ in periphery that exists in a $5 \mathrm{~km}$ distance from your residence. Of the five alternative treatment combinations (profiles) below, mark the one you most prefer.

\begin{tabular}{llllll}
\hline Attributes & Profile 1 & Profile 2 & Profile 3 & Profile 4 & Profile 5 \\
\hline Surroundings & walkways & fences & walkways & walkways & fences \\
Shoreline & concrete & boardwalks & natural & concrete & natural \\
Water quality & mid-low & mid-high & mid-low & high & low \\
Fish & mix & native & native & mix & alien \\
Cost $(¥ / \mathrm{mon})$ & 1,100 & 700 & 300 & 1,500 & 0 \\
\hline
\end{tabular}

Consider one Sara-type Tameike of the size about $1 \mathrm{~km}$ in periphery that exists in a $200 \mathrm{~m}$ distance from your residence. Of the five alternative treatment combinations (profiles) below, mark the one you most prefer.

\begin{tabular}{llllll}
\hline Attributes & Profile 1 & Profile 2 & Profile 3 & Profile 4 & Profile 5 \\
\hline Surroundings & walkways & fences & fences & walkways & fences \\
Shoreline & concrete & concrete & boardwalks & natural & natural \\
Water quality & mid-high & high & mid-low & mid-low & low \\
Fish & native & mix & native & alien & mix \\
Cost $¥ /$ mon) & 300 & 1,500 & 1,100 & 700 & 0 \\
\hline
\end{tabular}

Note: The survey was visually assisted with sample photos of Tameikes with different levels of attributes. 


\section{Appendix B: Conditional logit estimations}

Table 6 CL estimates with interactions for Yama-type Tameikes

\begin{tabular}{|c|c|c|c|}
\hline Variables & $\begin{array}{l}\text { Model } 1 \\
\text { Coefficient (s.e.) }\end{array}$ & $\begin{array}{l}\text { Model } 2 \\
\text { Coefficient (s.e.) }\end{array}$ & $\begin{array}{l}\text { Model } 3 \\
\text { Coefficient (s.e.) }\end{array}$ \\
\hline quality & $0.545(0.016)^{* * *}$ & $0.323(0.110)^{* * *}$ & $0.378(0.031)^{* * *}$ \\
\hline native & $0.851(0.032)^{* * *}$ & $0.871(0.227)^{* * *}$ & $0.416(0.078)^{* * *}$ \\
\hline walkways & $0.817(0.022)^{* * *}$ & $0.817(0.022)^{* * *}$ & $0.819(0.022)^{* * *}$ \\
\hline boardwalks & $0.290(0.026)^{* * *}$ & $0.304(0.026)^{* * *}$ & $0.298(0.026)^{* * *}$ \\
\hline concrete & $-0.438(0.031)^{* * *}$ & $-0.430(0.032)^{* * * *}$ & $-0.437(0.032)^{* * *}$ \\
\hline alien & $-0.341(0.038)^{* * *}$ & $-0.346(0.038) * * *$ & $-0.346(0.038)^{* * *}$ \\
\hline cost & $-0.001(0.000)^{* * *}$ & $-0.001(0.000)^{* * *}$ & $-0.001(0.000)^{* * *}$ \\
\hline age $\times q u a l i t y$ & & $0.000(0.001)$ & \\
\hline age $\times$ native & & $0.010(0.002)^{* * *}$ & $0.010(0.001)^{* * *}$ \\
\hline sex $\times$ quality & & $0.127(0.019)^{* * *}$ & $0.127(0.017)^{* * *}$ \\
\hline sex $\times$ native & & $-0.002(0.039)$ & \\
\hline employed $\times$ quality & & $0.015(0.021)$ & \\
\hline employed $\times$ native & & $-0.019(0.042)$ & \\
\hline married $\times$ quality & & $0.037(0.023)$ & \\
\hline married $\times$ native & & $0.066(0.048)$ & \\
\hline income $\times$ quality & & $0.006(0.018)$ & \\
\hline income $\times$ native & & $-0.061(0.038)$ & \\
\hline savings $\times$ quality & & $0.009(0.004)^{* *}$ & $0.010(0.004)^{* * *}$ \\
\hline savings $\times$ native & & $0.016(0.008)^{*}$ & $0.013(0.008)$ \\
\hline under $18 \times$ quality & & $0.019(0.021)$ & \\
\hline under $18 \times$ native & & $-0.076(0.042)^{*}$ & \\
\hline over $65 \times$ quality & & $-0.019(0.022)$ & \\
\hline over $65 \times$ native & & $0.089(0.044)^{* *}$ & $0.075(0.041)^{*}$ \\
\hline distance $\times$ quality & & $0.000(0.005)$ & \\
\hline distance $\times$ native & & $-0.025(0.010)^{* *}$ & \\
\hline size $\times q u a l i t y$ & & $0.087(0.027)^{* * *}$ & $0.088(0.027)^{* * *}$ \\
\hline size $\times$ native & & $-0.076(0.057)$ & $-0.072(0.056)$ \\
\hline Sample size & 16,000 & 16,000 & 16,000 \\
\hline Log likelihood & $-20,846$ & $-20,753$ & $-20,764$ \\
\hline HM statistic for IIA & $215.78 * * *$ & $347.96 * * *$ & $235.04 * * *$ \\
\hline
\end{tabular}

*** indicates significance at $1 \%$ level, $* *$ at $5 \%$, and $*$ at $10 \%$ 
Table 7 CL estimates with interactions for Sara-type Tameikes

\begin{tabular}{|c|c|c|c|}
\hline Variables & $\begin{array}{l}\text { Model } 4 \\
\text { Coefficient (s.e.) }\end{array}$ & $\begin{array}{l}\text { Model } 5 \\
\text { Coefficient (s.e.) }\end{array}$ & $\begin{array}{l}\text { Model } 6 \\
\text { Coefficient (s.e.) }\end{array}$ \\
\hline walkways & $-0.072(0.02)^{* * *}$ & $-1.158(0.206)^{* * *}$ & $-0.925(0.056)^{* * *}$ \\
\hline native & $-0.439(0.03)^{* * *}$ & $-0.316(0.233)$ & $-0.484(0.087)^{* * *}$ \\
\hline alien & $-0.363(0.03)^{* * *}$ & $-0.808(0.305)^{* * *}$ & $-1.055(0.114)^{* * *}$ \\
\hline boardwalks & $-0.438(0.03)^{* * *}$ & $-0.362(0.027)^{* * *}$ & $-0.362(0.027)^{* * *}$ \\
\hline concrete & $-0.299(0.03)^{* * *}$ & $-0.288(0.026)^{* * *}$ & $-0.288(0.026)^{* * *}$ \\
\hline quality & $-0.034(0.01)^{* * *}$ & $-0.072(0.013) * * *$ & $-0.072(0.013) * * *$ \\
\hline cost & $-0.001(0.00)^{* * * *}$ & $-0.001(0.000)^{* * *}$ & $-0.001(0.000)^{* * *}$ \\
\hline age $\times$ walkways & & $0.000(0.001)$ & \\
\hline age $\times$ native & & $0.005(0.002)^{* * *}$ & $0.006(0.001)^{* * *}$ \\
\hline age $\times$ alien & & $0.006(0.002)^{* * *}$ & $0.007(0.002)^{* * * *}$ \\
\hline sex $\times$ walkways & & $0.089(0.035)^{* *}$ & $0.087(0.034)^{* *}$ \\
\hline sex $\times$ native & & $0.121(0.040)^{* * *}$ & $0.132(0.039)^{* * *}$ \\
\hline sex $\times$ alien & & $0.145(0.052)^{* * *}$ & $0.143(0.050)^{* * *}$ \\
\hline employed $\times$ walkways & & $0.004(0.038)$ & \\
\hline employed $\times$ native & & $-0.035(0.044)$ & \\
\hline employed $\times$ alien & & $0.027(0.057)$ & \\
\hline married $\times$ walkways & & $0.041(0.044)$ & \\
\hline married $\times$ native & & $0.081(0.049)$ & $0.064(0.040)$ \\
\hline married $\times$ alien & & $0.082(0.064)$ & \\
\hline income $\times$ walkways & & $0.026(0.034)$ & \\
\hline income $\times$ native & & $-0.029(0.039)$ & \\
\hline income $\times$ alien & & $-0.063(0.051)$ & \\
\hline savings $\times$ walkways & & $0.008(0.008)$ & \\
\hline savings $\times$ native & & $0.021(0.009)^{* * *}$ & $0.013(0.007)^{*}$ \\
\hline savings $\times$ alien & & $0.025(0.011)^{* * *}$ & \\
\hline under $18 \times$ walkways & & $0.013(0.039)$ & \\
\hline under $18 \times$ native & & $0.005(0.044)$ & \\
\hline under $18 \times$ alien & & $0.102(0.057)^{*}$ & $0.113(0.048)^{* *}$ \\
\hline over $65 \times$ walkways & & $0.026(0.040)$ & \\
\hline over $65 \times$ native & & $-0.009(0.045)$ & \\
\hline over $65 \times$ alien & & 0.009 (0.059) & \\
\hline distance $\times$ walkways & & $1.082(0.059)^{* * *}$ & $1.081(0.059)^{* * *}$ \\
\hline distance $\times$ native & & $0.148(0.057)^{* * *}$ & $0.149(0.057)^{* * *}$ \\
\hline distance $\times$ alien & & $-0.713(0.075) * * *$ & $-0.716(0.075)^{* * *}$ \\
\hline size $\times$ walkways & & $0.197(0.051)^{* * *}$ & $0.197(0.051)^{* * * *}$ \\
\hline size $\times$ native & & $-0.765(0.059) * * *$ & $-0.766(0.059)^{* * *}$ \\
\hline size $\times$ alien & & $0.765(0.080)^{* * *}$ & $0.762(0.080)^{* * *}$ \\
\hline Sample size & 16,000 & 16,000 & 16,000 \\
\hline Log likelihood & $-23,976$ & $-23,434$ & $-23,442$ \\
\hline HM statistic for IIA & $1326.70^{* * *}$ & $1674.36^{* * *}$ & $1664.77 * * *$ \\
\hline
\end{tabular}

$* * *$ indicates significance at $1 \%$ level, $* *$ at $5 \%$, and $*$ at $10 \%$ 
Table 8 Marginal willingness to pay (via CL) for Tameike attributes in JPY/month

\begin{tabular}{|c|c|c|c|c|c|c|}
\hline \multirow[b]{2}{*}{ Variables } & \multicolumn{3}{|c|}{ Yama-types } & \multicolumn{3}{|c|}{ Sara-types } \\
\hline & Model 1 & Model 2 & Model 3 & Model 4 & Model 5 & Model 6 \\
\hline walkways & 743 & 744 & 741 & -115 & $-1,597$ & $-1,277$ \\
\hline boardwalks & 264 & 277 & 270 & -701 & -500 & -500 \\
\hline concrete & -399 & -392 & -395 & -480 & -398 & -398 \\
\hline quality & 495 & 295 & 342 & -55 & -99 & -99 \\
\hline native & 774 & 794 & 376 & -703 & -436 & -668 \\
\hline alien & -310 & -315 & -313 & -582 & $-1,114$ & $-1,457$ \\
\hline
\end{tabular}

\section{References}

Adamowicz W, Louviere J, Williams M (1994) Combining revealed and stated preference methods for valuing environmental amenities. J Environ Econ Manag 26(3):271-292. doi:10.1006/jeem.1994.1017

Bateman I, Cole M, Georgiou S, Hadley D (2006) Comparing contingent valuation and contingent ranking: a case study considering the benefits of urban river water quality improvements. J Environ Manag 79(3):221-231. doi:10.1016/j.jenvman.2005.06.010

Birol E, Das S (2010) Estimating the value of improved wastewater treatment: the case of River Ganga, India. J Environ Manag 91(11):2163-2171. doi:10.1016/j.jenvman.2010.05.008

Birol E, Karousakis K, Koundouri P (2006) Using a choice experiment to account for preference heterogeneity in wetland attributes: the case of Cheimaditida wetland in Greece. Ecol Econ 60(1):145-156. doi:10.1016/j.ecolecon.2006.06.002

Birol E, Hanley N, Koundouri P, Kountouris Y (2009) Optimal management of wetlands: quantifying trade-offs between flood risks, recreation, and biodiversity conservation. Water Resour Res 45(11), doi:10.1029/2008WR006955

Carlsson F, Frykblom P, Liljenstolpe C (2003) Valuing wetland attributes: an application of choice experiments. Ecol Econ 47(1):95-103. doi:10.1016/j.ecolecon.2002.09.003

Groenfeldt D (2006) Multifunctionality of agricultural water: looking beyond food production and ecosystem services. Irrig Drain 55(1):73-83. doi:10.1002/ird.217

Hanley N, Wright RE, Alvarez-Farizo B (2006) Estimating the economic value of improvements in river ecology using choice experiments: an application to the water framework directive. J Environ Manag 78(2):183-193. doi:10.1016/j.jenvman.2005.05.001

Hensher D, Rose J, Greene W (2005) Applied choice analysis: a primer. Cambridge University Press

Lancaster KJ (1966) A new approach to consumer theory. J Polit Econ 74:132

MAFF (2013) Rural Development Bureau, Ministry of Agriculture, Forestry and Fisheries, Japan. http:// www.maff.go.jp/j/nousin/index.html

Martin-Ortega J, Giannoccaro G, Berbel J (2011) Environmental and resource costs under water scarcity conditions: an estimation in the context of the European water framework directive. Water Resour Manag 25(6):1615-1633. doi:10.1007/s11269-010-9764-z

Matsuno Y, Nakamura K, Masumoto T, Matsui H, Kato T, Sato Y (2006) Prospects for multifunctionality of paddy rice cultivation in Japan and other countries in monsoon Asia. Paddy Water Environ 4(4):189197. doi:10.1007/s10333-006-0048-4

McFadden D, Train K (2000) Mixed MNL models for discrete response. J Appl Econ 15(5):447-470. doi:10.1002/1099-1255(200009/10)15:5<447::AID-JAE570>3.0.CO;2-1

Morita M (1982) Tameike seibi no genjo to kadai [in Japanse]. Japanese association for the study of irrigation. Drain Reclam Eng 50:7-20

Morrison M, Bennett J, Blamey R (1999) Valuing improved wetland quality using choice modeling. Water Resour Res 35(9):2805-2814. doi:10.1029/1999WR900020

Othman J, Bennett J, Blamey R (2004) Environmental values and resource management options: a choice modelling experience in Malaysia. Environ Dev Econ 9:803-824. doi:10.1017/S1355770X04001718

Train KE (2009) Discrete choice methods with simulation. Cambridge Books, Cambridge University Press 